\title{
Erosion Modeling in Parallel Gate Valve
}

\section{Jong Hyok Ri}

Doctoral Student Petroleum-Gas University of Ploiestti Faculty of Mechanical and Electrical Engineering Romania

Razvan-George Ripeanu

Professor

Petroleum-Gas University of Ploiestt Faculty of Mechanical and Electrical Engineering Romania

Alin Dinita

Assistent Professo Petroleum-Gas University of Ploiestt Faculty of Mechanical and Electrical Engineering Romania
Gate valves, which are widely used in oil production and transportation processes, can be eroded by high fluid pressures and sand particles contained in crude oil during operation. This erosion can result in loss of valve thickness and shutdown of the operating system. Erosion is not uniform on valve elements, and it is different depending on the stages of opening the valve. In this paper, flow analysis and erosion rate analysis for the fluid flowing through the valve in different stages of opening were performed by using ANSYS Fluent 19.2. The gate valve model was designed by using AutoCAD, and the geometric dimensions and physical properties of the material required for modeling were determined according to the specifications of the gate valve installed in the oil pipeline. By the Reynolds calculation, it was disclosed that the fluid which flows in the valve has the characteristic of turbulent flow, and based on this calculation, the inlet length of the valve was determined. For the CFD analysis, the Euler method and the method of Lagrange were used. Using the $k-\varepsilon$ and DPM models according to the fluid characteristics of the turbulent flow, it was predicted the erosion rates of the surface generated by the sand which is the solid phase dispersed in the multiphase fluid. In addition, based on the Von Mises method and the pressure distribution, data obtained by fluid analysis, the process of calculating the stress on the closing elements was presented. The fluid used in the analysis was petroleum with sand particles.

Keywords : Parallel gate valve, erosion, turbulent, meshing, polyphase, sand

\section{INTRODUCTION}

Internationally, energy security is an important issue for the country's economy and stability. As the demand for energy and its production increases, the reliability requirements for the valve, which is an important element in the oil transport process, also increase day by day.

Gate valves, which are widely used in oil production and transport processes, can be eroded by the high pressure of the fluids and by the sand particles contained in them during operation. In particular, erosion by sand particles or liquid jets may occur locally in the part of the gate or seat where fluid flow changes rapidly when the gate is open or closed (Figure 1).

Such erosion can lead to the loss of the thickness of the parts and can even stop the valve system.

Therefore, predicting the degree of erosion and weakness of the valve in advance is an important requirement for increasing the durability of the valve and for ensuring the fluid flow safely.

The position and severity of the erosion of the valve are related to the opening situation of the gate, the speed of the fluid, the material of the valve, the size and distribution of the sand particles and it' s impact angle, [1,2].

In general, the erosion rate can be predicted using the empirical formulas presented at API (American

Received: May 2020, Accepted: July 2020

Correspondence to: Prof.Dr.Eng. Razvan George

Ripeanu, Petroleum-Gas University of Ploiesti,

Blvd. Bucuresti 39, 100680 Ploiesti, Romania

E-mail: rrapeanu@upg-ploiesti.ro

doi: $10.5937 /$ fme2004808H

(C) Faculty of Mechanical Engineering, Belgrade. All rights reserved
Petroleum Institute) [3] and Erosion / Corrosion Research Center (E / CRC) (McLaury and Shirazi, 1999) [4]. It is difficult to predict the erosion rate changes depending on the solid particle ratio and the rapid changes of the fluid that passes inside the gate valve only by the empirical methods.

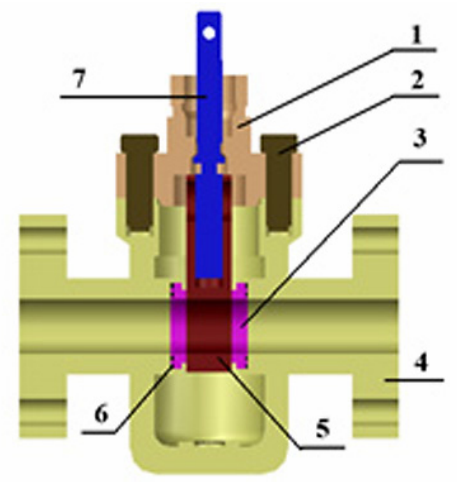

1 Bonnet, 2 Bonnet bolting, 3 Seat, 4 Body

5 Gate assembly, 6 Seat ring, 7 Stem

Figure 1. Parallel gate valve elements

Many scientists, including Sheldon (1966), Goodwin (1969), Head (1970), Sheldon (1970), Grant (1973), Williams (1974), and Sundararajan (1983) presented a general equation to predict the rates of erosion due to solid particles [5], but the empirical equations presented did not reflect the contents related to the velocity and the angle of impact of the particles.

McLaury et al. (1996) presented a model to predict the rate of erosion of the sand particles in water [6] and also Edwards et al. (1998) proposed a model to predict 
the rates of erosion in polyphase fluids using the CFD method, [7].

Oka et el. (2005) conducted many experiments to reveal the influence of sand particles in the fluid on erosion of the pipe wall and during this process, presented a calculation equation for prediction of the rates of erosion, [8].

On the other hand, G.V. Messa et al. (2017) predicted the rate of erosion of the gate valve by combining with the CFD model and the model of erosion proposed by $\mathrm{Oka}$, and presented a calculation equation to predict the life of the valve using MATLAB E-Code, [9].

Also, Det Norske Veritas(DNV) (2007) presented a calculation equation that considers the velocity and the angle of impact for predicting the rate of erosion in a system of the pipes through which polyphasic fluid flows, [10].

But, despite many studies, none of the empirical equations hasn't predicted the rate of erosion fully and accurately yet. For these reasons, it can be said that the combination of the experimental method and the CFD analysis method is the most effective way for accurate prediction of erosion rate.

The present study presented an analysis model for predicting erosion wear that would occur in a gate valve and the values of stresses for evaluating its structural stability in diferent stages of valve gate opening when the polyphase fluid containing petroleum and sand passes through it.

\section{CONSTRUCTION MODELLING}

\subsection{Design of the geometric shape of the gate valve}

The valve model was designed by using AutoCAD according to the standard and operating conditions of type $21 / 16^{\prime \prime}-3 / 5 \mathrm{M}$ type gate valve actually installed in the oil pipeline.

The thing we should pay attention to at the design of the geometrical shape of the valve, is the length of the pipe installed on the inlet side of the valve. In general, the valve is installed in the straight portion of the pipe, so when the fluid hits the gate surface of the valve, the fluid usually collides in a fully developed flow state.

Table 1. Geometric dimensions of valve model and the parameter values

\begin{tabular}{|c|c|c|}
\hline Type & Unit & Value \\
\hline $\begin{array}{c}\text { The length of the pipe from the } \\
\text { entrance }\end{array}$ & $\mathrm{mm}$ & 1400 \\
\hline The length of the pipe from the exit & $\mathrm{mm}$ & 147.5 \\
\hline The diameter of the valve & $\mathrm{mm}$ & 52.4 \\
\hline Seat thickness & $\mathrm{mm}$ & 15.7 \\
\hline Seat diameter & $\mathrm{mm}$ & 52.4 \\
\hline The thickness of the gate & $\mathrm{mm}$ & 44.6 \\
\hline Diameter of gate & $\mathrm{mm}$ & 52.4 \\
\hline Fluid pressure at the inlet & $\mathrm{MPa}$ & 35 \\
\hline Fluid temperature & ${ }^{\circ} \mathrm{C}$ & 20 \\
\hline Fluid flow velocity at the inlet & $\mathrm{m} / \mathrm{s}$ & 20 \\
\hline Reynolds number & - & 59181 \\
\hline Fluid density & $\mathrm{kg} / \mathrm{m}^{3}$ & 960 \\
\hline Fluid viscosity & $\mathrm{kg} /(\mathrm{m} \bullet \mathrm{s})$ & 0.017 \\
\hline \multicolumn{2}{|c}{} \\
\hline
\end{tabular}

Table 2. Material list of gate valve parts

\begin{tabular}{|c|c|c|}
\hline Poz item & Type of piece & Material \\
\hline 1 & Body & A 487 \\
\hline 2 & Gate & AISI 4130 \\
\hline 3 & Seat & AISI 4130 \\
\hline 4 & Stem & AISI 4130 \\
\hline 5 & Seat ring & AISI 1018 \\
\hline 6 & Bonnet & A 487 \\
\hline 7 & Bonnet bolting & ASTM A194 \\
\hline
\end{tabular}

In the paper, considering this, the pipe length of the valve inlet was set long enough when designing the valve model. In this case, the inlet length of the pipe was calculated using the Reynolds Number and the diameter of the valve.

In $\mathrm{CFD}$ (Computational fluid dynamics) analysis, erosion occurs only on the surface of the model, so the valve body has been replaced with a pipe to reduce the calculation speed.

Table 1 presents the geometrical dimensions of the model and other parameters used in the analysis, and Table 2 presents the material list of the valve parts.

Calculation of the Reynolds number:

$$
\begin{aligned}
& R_{e}=\frac{\rho \cdot v \cdot D}{\mu} \\
& R_{e}=\frac{960 \cdot 20 \cdot 5.24 \cdot 10^{-2}}{0.017}=59181.18
\end{aligned}
$$

When calculating the Reynolds number for the fluid flowing in the valve, it has turbulent flow characteristics, so the length of the pipe can be determined by using the equations of Muzychka and Yovanovich, [11].

$$
\begin{aligned}
& L_{\text {tube,turbulent }}=4.4 \cdot D \cdot \operatorname{Re}_{D}^{\frac{1}{6}} \\
& L_{\text {tube,turbulent }}=4.4 \cdot 2.4 \cdot 59181^{\frac{1}{6}}=1439.3 \mathrm{~mm}
\end{aligned}
$$

To facilitate the discretization of the model, the length of the pipe at the entrance of the valve was set to $1400 \mathrm{~mm}$.

\subsection{Discrete composition}

To increase the intuition of the model and the calculation speed, the hexagonal discretization method was used.

Since the velocity distribution of the fluid in the gate part changes rapidly and the erosion model being used is a model related to the surface of the valve and the pipe, the mesh size was set from the hydrodynamic point of view.

The height of the surface element was calculated using the $y^{+}$method (Wall Distance Method), [12].

$$
\begin{gathered}
C_{\mathrm{f}}=\left[2 \cdot \log _{10}\left(R_{e}\right)-0.65\right]^{-2.3} \quad\left(R_{e}<10^{9}\right) \\
\tau_{\mathrm{w}}=C_{\mathrm{f}} \cdot \frac{1}{2} \cdot \rho \cdot u^{2}
\end{gathered}
$$




$$
\begin{aligned}
& u_{\text {fric }}=\sqrt{\frac{\tau_{w}}{\rho}} \\
& y^{+}=\frac{u_{\text {fric }} \cdot y \cdot \rho}{\mu}
\end{aligned}
$$

In the above equation, the $y^{+}$range is from 30 to 500 , but the $y^{+}$value was chosen as 50 to finely divide to fit the erosion model and the discretization size was calculated $\left(y=3.5 \cdot 10^{-3} \mathrm{~m}\right)$.

The discretization form for the erosion model is presented in Figure 2. Was used a 194372 number of cells, with cell size of $3.5 \mathrm{~mm}, 193611$ nodes, 1 second time step size, 3600 number of time steps, and 50 max iterations / time step.

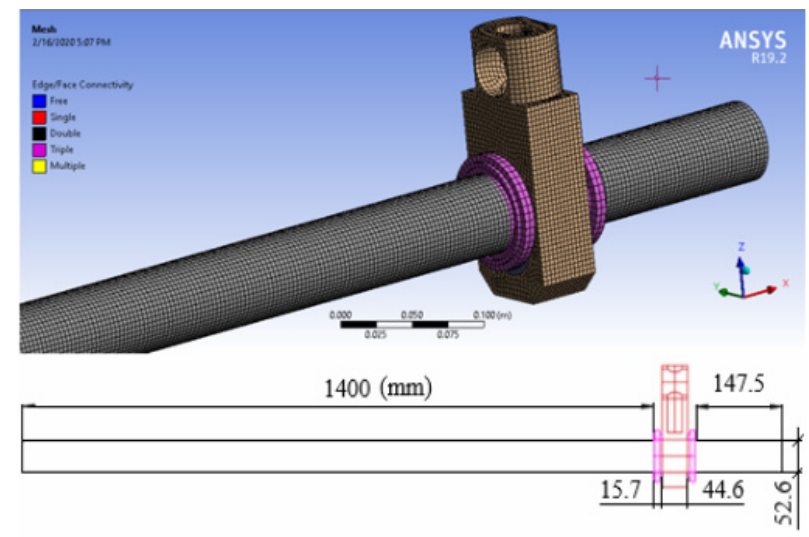

Figure 2. Discretization form for the erosion model

\section{FLUID FLOW MODELING AND EROSION RATE CALCULATION}

\subsection{Fluid flow modeling}

In the paper, the fluid flow characteristics were calculated using ANSYS Fluent 19.2.

In solving the governing equations in hydrodynamics, the continuous phase has been calculated by Euler's method and the dispersed phase has been calculated by the Lagrange method of tracking the individual particles.

For the continuous phase, the oil specified in the list of materials on the computer has been selected, and for the dispersed phase, the sand which was the main cause of erosion has been selected.

It has been assumed that the continuous and kinetic equations of the fluid flowing through the valve are equations (7) and (8), [13].

$$
\begin{aligned}
& \frac{\partial \rho}{\partial t}+\frac{\partial}{\partial x_{\mathrm{j}}}\left(\rho \cdot U_{\mathrm{j}}\right)=0 \\
& \frac{\partial\left(\rho \cdot U_{\mathrm{i}}\right)}{\partial t}+\frac{\partial}{\partial x_{\mathrm{j}}}\left(\rho \cdot U_{\mathrm{i}} \cdot U_{\mathrm{j}}\right)=-\frac{\partial p^{\prime}}{\partial x_{\mathrm{j}}}+ \\
& +\frac{\partial}{\partial x_{\mathrm{j}}}\left(\sigma_{\mathrm{ij}}+\tau_{\mathrm{ij}}\right)+\rho \cdot g_{\mathrm{i}}+S_{\mathrm{p}}
\end{aligned}
$$

Here, the viscous tensor $\sigma_{\mathrm{ij}}$ is calculated by equation (9), [13]

$$
\sigma_{\mathrm{ij}}=\mu\left(\frac{\partial U_{\mathrm{i}}}{\partial x_{\mathrm{j}}}+\frac{\partial U_{\mathrm{j}}}{\partial x_{\mathrm{i}}}-\frac{2}{3} \delta_{\mathrm{ij}} \frac{\partial U_{\mathrm{k}}}{\partial x_{\mathrm{k}}}\right),
$$

where[13]

$$
\begin{aligned}
& S_{\mathrm{ij}}=\frac{1}{2}\left(\frac{\partial U_{\mathrm{i}}}{\partial x_{\mathrm{j}}}+\frac{\partial U_{\mathrm{j}}}{\partial x_{\mathrm{i}}}\right), \\
& S_{\mathrm{ij}}^{\mathrm{dev}}=\frac{1}{2}\left(\frac{\partial U_{\mathrm{i}}}{\partial x_{\mathrm{j}}}+\frac{\partial U_{\mathrm{j}}}{\partial x_{\mathrm{i}}}-\frac{2}{3} \cdot \delta_{\mathrm{ij}} \cdot \frac{\partial U_{\mathrm{k}}}{\partial x_{\mathrm{k}}}\right) .
\end{aligned}
$$

Since it is not possible to directly solve the stress tensor, the differential equation is solved by applying the gradient- transfer hypothesis.

$$
\begin{aligned}
\tau_{\mathrm{ij}} & =2 \mu_{\mathrm{t}} \cdot\left(S_{\mathrm{ij}}^{\mathrm{dev}}\right)-\frac{2}{3} \rho \cdot k \cdot \delta_{\mathrm{ij}},[13] \\
\mu_{\mathrm{t}} & =C_{\mu} \cdot \rho \cdot \frac{k^{2}}{\varepsilon} \cdot[13]
\end{aligned}
$$

These values depend on the type of the $k-\varepsilon$ model. In this study, the realizable $k-\varepsilon$ model was used for the turbulence model. The realizable $k-\varepsilon$ model is a turbulence model for analyzing the action process of a fluid with a relatively high Reynolds number at the wall boundary surface.

In this model, $k$ and $\varepsilon$ are calculated by the following equations (14) and (16), [13,14,15,16].

$$
\begin{aligned}
& \frac{\partial(\rho \cdot k)}{\partial t}+\frac{\partial\left(\rho \cdot U_{\mathrm{j}} \cdot k\right)}{\partial x_{\mathrm{j}}}=\frac{\partial}{\partial x_{\mathrm{j}}}\left[\left(\mu+\frac{\mu_{\mathrm{t}}}{\sigma_{\mathrm{k}}}\right) \cdot \frac{\partial k^{\prime}}{\partial x_{\mathrm{j}}}\right]+ \\
& +P-\rho \cdot \varepsilon \\
& \frac{\partial(\rho \cdot \varepsilon)}{\partial t}+\frac{\partial\left(\rho \cdot U_{j} \cdot \varepsilon\right)}{\partial x_{j}}=\frac{\partial}{\partial x_{j}}\left[\left(\mu+\frac{\mu_{t}}{\sigma_{\varepsilon}}\right) \cdot \frac{\partial \varepsilon^{\prime}}{\partial x_{j}}\right]+ \\
& +C_{1} \cdot \varepsilon \cdot \rho \cdot S-C_{\varepsilon 2} \cdot \rho \cdot \frac{\varepsilon^{2}}{k+\sqrt{(\mu / \rho) \cdot \varepsilon}}
\end{aligned}
$$

where,

$$
P=\tau_{\mathrm{ij}} \cdot \frac{\partial U_{\mathrm{i}}}{\partial x_{\mathrm{j}}},
$$

or

$$
P=G-\frac{2}{3} \cdot \rho \cdot k \cdot \frac{\partial U_{\mathrm{k}}}{\partial x_{\mathrm{k}}},
$$

$$
\begin{gathered}
G=2 \mu_{\mathrm{t}} \cdot S_{\mathrm{ij}}^{\mathrm{dev}} \cdot \frac{\partial U_{\mathrm{i}}}{\partial x_{\mathrm{j}}}=2 \mu_{\mathrm{t}}\left[S_{\mathrm{ij}} \cdot S_{\mathrm{ij}}-\frac{1}{3}\left(\frac{\partial U_{\mathrm{k}}}{\partial x_{\mathrm{k}}}\right)^{2}\right], \\
C_{1}=\max \left(0.43, \frac{\eta}{\eta+5}\right) \\
\eta=\frac{k}{\varepsilon} \sqrt{2 \cdot S_{i j} \cdot S_{i j}} \\
C_{\mu}=\frac{1}{A_{0}+A_{\mathrm{s}} \cdot\left(U^{*} \cdot k / \varepsilon\right)}
\end{gathered}
$$




$$
\begin{gathered}
U^{*}=\sqrt{S_{\mathrm{ij}} \cdot S_{\mathrm{ij}}+\Omega_{\mathrm{ij}} \cdot \Omega_{\mathrm{ij}}}, \\
\Omega_{\mathrm{ij}}=\frac{1}{2}\left(\frac{\partial U_{\mathrm{i}}}{\partial x_{\mathrm{j}}}-\frac{\partial U_{\mathrm{j}}}{\partial x_{\mathrm{i}}}\right), \\
A_{\mathrm{s}}=\sqrt{6} \cos (\varphi), \varphi=\frac{1}{3} \arccos (\sqrt{6} \cdot W), \\
W=\min \left[\max \left(2 \sqrt{2} \frac{S_{i j} \cdot S_{j k} \cdot S_{i k}}{S^{3}},-\frac{1}{\sqrt{6}}\right), \frac{1}{\sqrt{6}}\right]
\end{gathered}
$$

In the equations above, the constants are $: \sigma_{\mathrm{k}}=1.0$, $\sigma=1.2, C_{2}=1.9, A_{0}=4.0[13,14]$.

\subsection{Calculation of erosion rate}

DPM (Discrete Phase Model) model was used as an erosion model. DPM model can be used in case that the continuous phase acts together with the dispersed phase. In the DPM model, it is assumed that the continuous phase exerts a force on the dispersion phase, but the dispersion phase does not affect the continuous phase.

This assumption is possible when the dispersed phase contained in the fluid is less than $10 \%$ and there is no significant effect [6]. In this study, a DPM model can be used because fluid analysis is performed on petroleum with less than $10 \%$ sand as impurities.

In the paper, erosion rate was predicted by using the Generic Erosion Model that ANSYS Fluent has. In this case, the particle erosion rate is calculated by equation (26).

$$
R=\sum_{p=1}^{N_{\text {particles }}} \frac{m_{\mathrm{p}} \cdot C\left(d_{\mathrm{p}}\right) \cdot f(\gamma) \cdot V^{\mathrm{b}(v)}}{A_{\text {face }}},[17]
$$

The erosion rate was calculated assuming $C=1.8 \cdot 10$ ${ }^{9}, f=1$, and $b=0 . C, f$ and $b$ are not defined by the material property values, but by the wall boundary conditions of the analytical model. Therefore, when defining the boundary conditions of the model, appropriate values for solving equations should be given.

Table 3. Parallel Gate Valve Erosion Parameters

\begin{tabular}{|c|c|c|c|}
\hline Item & Parameters & Unit & Value \\
\hline 1 & Particle Diameter & $\mathrm{m}$ & $1 \cdot 10^{-4}$ \\
\hline 2 & Particle inlet velocity & $\mathrm{m} / \mathrm{s}$ & 20 \\
\hline 3 & Particle flow rate & $\mathrm{kg} / \mathrm{s}$ & 0.2 \\
\hline 4 & Particle Density & $\mathrm{kg} / \mathrm{m}^{3}$ & 1550 \\
\hline 5 & Action time of particle & $\mathrm{s}$ & 3600 \\
\hline
\end{tabular}

Table 3 presents the values of the parameters used in the erosion calculation.

\subsection{Calculation results and analysis}

Based on the model proposed above, the flow characteristics of the fluid and the change of erosion rates were observed, dividing the state of opening and closing of the valve in 4 cases.

In the analysis, the characteristic values of the fluid and particles were given at the inlet, and the relative pressure was taken into account at the outlet by giving the opening condition.

To fit the erosion model, the wall boundary condition of the model was set to the condition of No slip wall, and the operating time of the particle was set to 3600 seconds.

First, the flow characteristics of the fluid and the state of pressure change according to the state of opening and closing of the valve are presented in Figures 3 and 4, and the calculation results are presented in Figures 5 and 6 and in Tables 4 and 5.
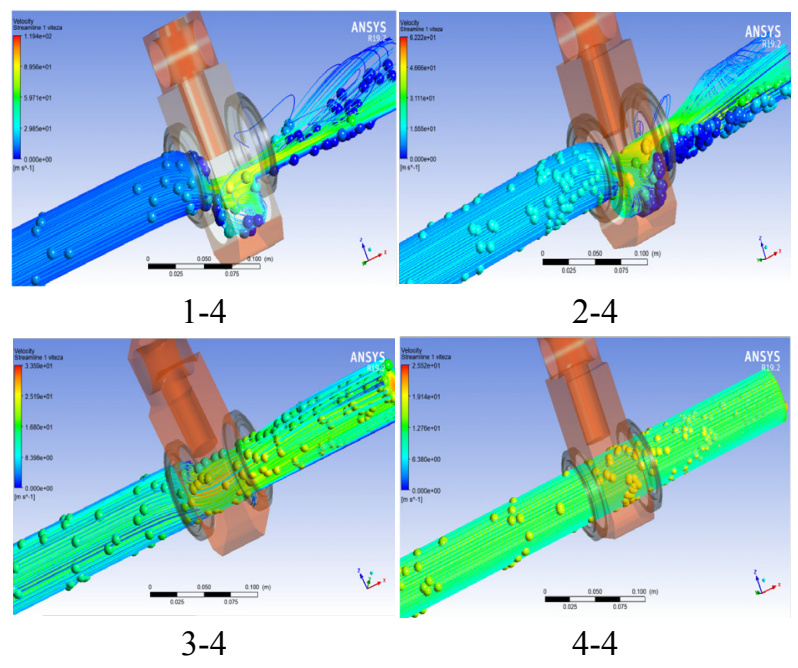

Figure 3. Flow changes of fluid depending on the opening and closing state of the gate

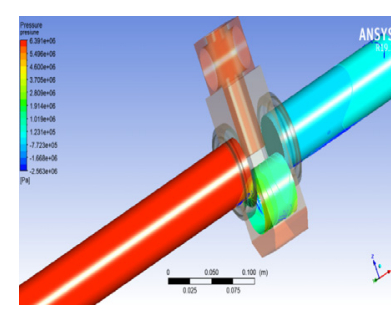

$1-4$
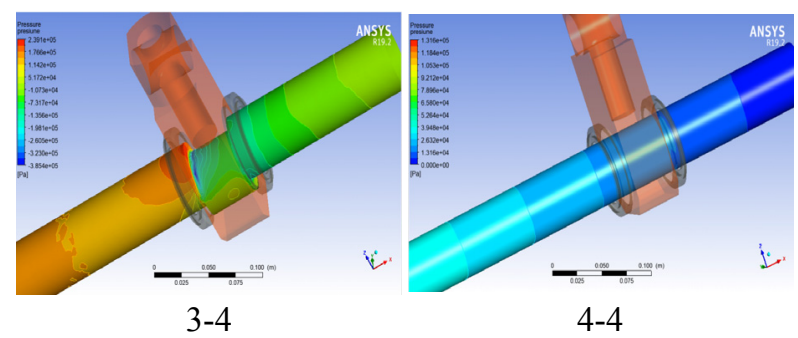

Figure 4. Pressure distributions of fluid depending on the opening and closing state of the gate

As shown in Figures 5 and 6, it can be seen that the smaller the passage area of the fluid is, the greater the velocity of the fluid and the pressure applied to the valve are.

In the figures above, 1-4 is the valve in which the gate was opened by only about a quarter, $2-4$ is the valve in which the gate was opened by only half, 3-4 is the valve in which the gate was opened by only three fourths, 4-4 is the valve in which the gate opened completely. 
In addition, except for the valve in which the gate was opened completely, when it is observed in the same valve, the velocity of a fluid was higher in seat 2 and in the part of the gate in which the direction of fluid flow changes rapidly.

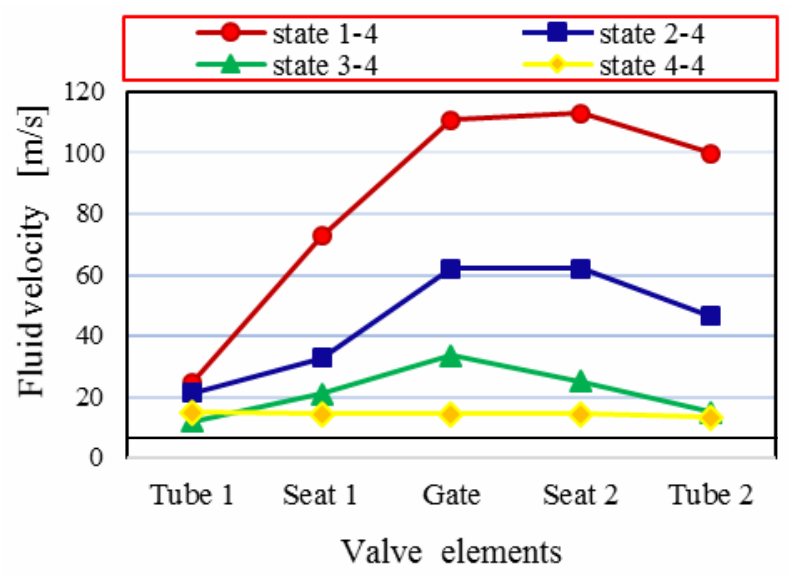

Figure 5. Changes of fluid flow velocity according to the open/close state of the gate

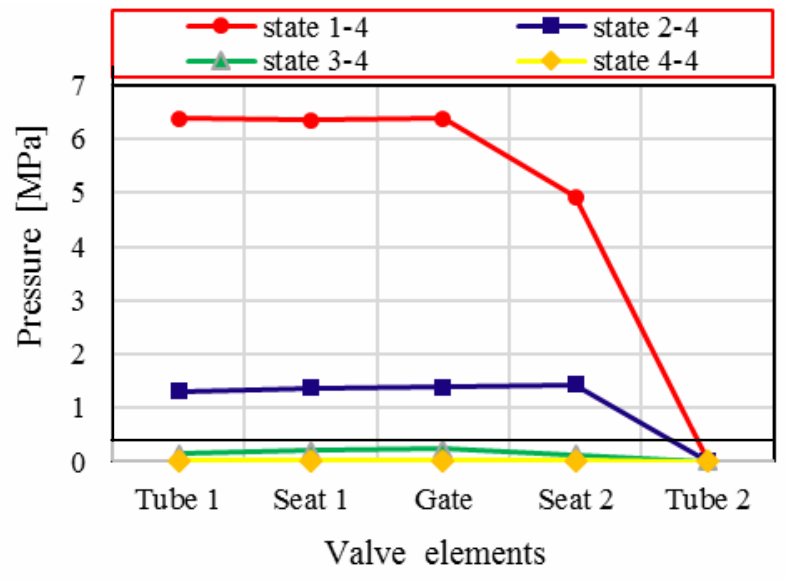

Figure 6. Changes of fluid pressure according to the open/close state of the gate

In particular, as the passage area of the fluid became smaller, the fluid vortex phenomenon inside and behind the gate appeared more severely. The value of the pressure was also higher in the gate section and gradually decreased as it went to tube 2 .

In this case, the maximum pressure appeared on the surface of the wall in front of the gate which is in direct contact with the fluid and, in rare cases, near the contact boundary between the fluid passage surface of the gate and the lower section of the seat. The reason for this is that as the fluid passage area decreases, a vortex is generated inside and behind the gate.

When the valve gate is opened completely, the pressure and velocity of the fluid gradually decreased as it went to tube 2 . In this case, there are pressure losses only due to the friction between the fluid and the pipe wall.

Next, the erosion state of the valve and the calculation results are presented in Figures 7 and 8 and in Table 6.

The rate of erosion also increased as the fluid flow area decreased, and the flow characteristics changed rapidly.

In addition, as can be seen in Figure 7, except for the valve in which the gate was fully opened, erosion first occurred on the surface of the tubel in front of the gate and on the inner surface of the gate, and this was gradually transferred to the back of the gate, as the gate is closed.

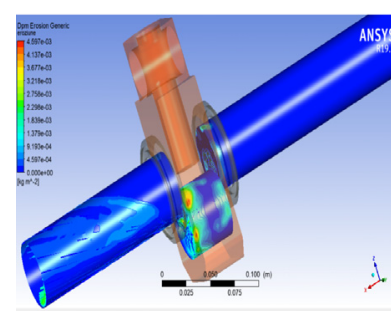

$1-4$

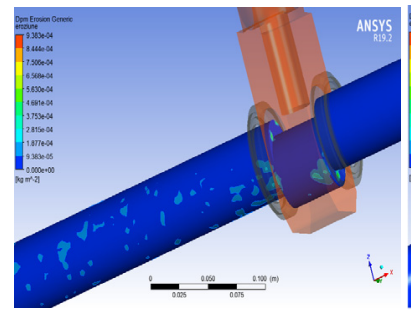

$3-4$

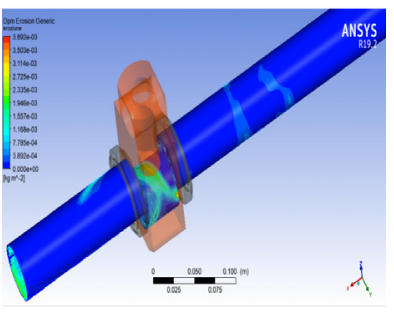

$2-4$

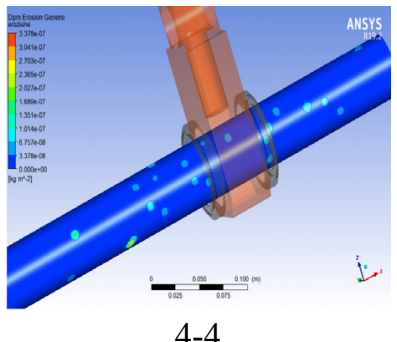

4-4
Figure 7. Erosion states due to sand particles according to the opening and closing state of the gate valve

In particular, erosion was severely generated on the inner surface of the gate and at the boundary between the gate and the seat 2 .

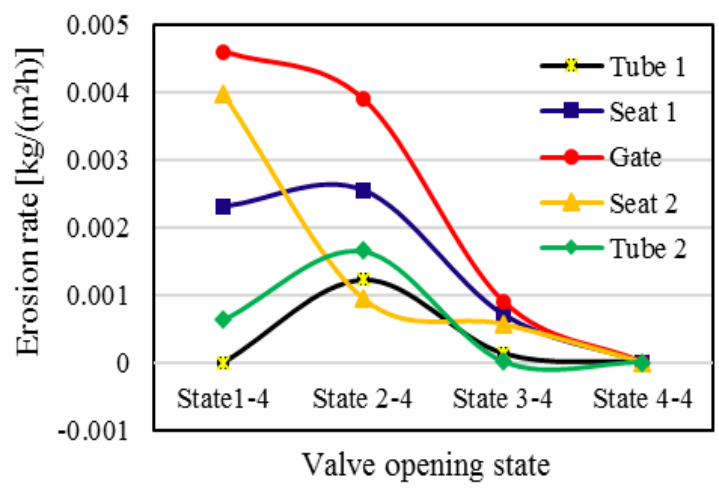

Figure 8. Erosion rate changes due to sand particles according to the opening and closing state of the gate valve

Further, when the gate was closed by a quarter, most of the erosion occurred near the boundary between the inner surface of the gate and the lower section of the seat 2 and on the inner surface of the tube 2. The reason for this is that a stronger vortex was generated inside the gate and inside the seat 2 and the tube 2 behind the gate, as the fluid passage area is gradually decreased.

In all cases, the erosion rate was recorded as the maximum value on the inner surface of the gate and it was $4.597 \cdot 10^{-3} \mathrm{~kg} /\left(\mathrm{m}^{2} \mathrm{~h}\right)$ when the valve was opened by only $1 / 4$. In addition, when the valve was fully opened, erosion occurred accidentally along the entire length of the pipe (tubes).

\section{STRESSES CALCULATION ON CLOSING ELEMENTS}

Depending on the pressure distribution data obtained by CFD analysis, the stress states of the closing elements were analyzed according to the open state of the valve. 
Table 4. Calculation results of fluid flow velocity according to the open/closed state of the valve

\begin{tabular}{|c|c|c|c|c|c|}
\hline \multirow{2}{*}{$\begin{array}{c}\text { Valve open } \\
\text { state }\end{array}$} & \multicolumn{5}{|c|}{ Fluid flow velocity [m/s] } \\
\cline { 2 - 6 } & Tub 1 & Seat 1 & Gate & Seat 2 & Tub 2 \\
\hline $1-4$ & 24.5 & 72.8 & 110.9 & 113 & 99.8 \\
\hline $2-4$ & 21.3 & 32.7 & 62.2 & 62 & 46.6 \\
\hline $3-4$ & 12 & 21 & 33.5 & 25.2 & 15 \\
\hline $4-4$ & 15 & 14.5 & 14.3 & 14.3 & 13.4 \\
\hline
\end{tabular}

Table 5. Calculation results of fluid pressure according to the open/closed state of the valve

\begin{tabular}{|c|c|c|c|c|c|}
\hline \multirow{2}{*}{$\begin{array}{c}\text { Valve open } \\
\text { state }\end{array}$} & \multicolumn{5}{|c|}{ Fluid pressure $[\mathrm{Pa}]$} \\
\cline { 2 - 6 } & Tub 1 & Seat 1 & Gate & Seat 2 & Tub 2 \\
\hline $1-4$ & 6390000 & 6358000 & 6380000 & 4917000 & 6073 \\
\hline $2-4$ & 1314000 & 1370000 & 1390000 & 1430000 & 135 \\
\hline $3-4$ & 151302 & 211193 & 239000 & 121856 & 91 \\
\hline $4-4$ & 27730 & 18840 & 16404 & 13434 & 4885 \\
\hline
\end{tabular}

Table 6. Calculation results of erosion rates by sand particles according to the open/closed state of the valve

\begin{tabular}{|c|c|c|c|c|c|}
\hline \multirow{2}{*}{$\begin{array}{c}\text { Valve open } \\
\text { state }\end{array}$} & \multicolumn{5}{|c|}{ Erosion rates $\left[\mathrm{kg} /\left(\mathrm{m}^{2} \cdot \mathrm{h}\right)\right]$} \\
\cline { 2 - 6 } & Tub 1 & Seat 1 & Gate & Seat 2 & Tub 2 \\
\hline $1-4$ & & $2.3 \cdot 10^{-3}$ & $4.597 \cdot 10^{-3}$ & $3.963 \cdot 10^{-3}$ & $6.325 \cdot 10^{-4}$ \\
\hline $2-4$ & $1.230 \cdot 10^{-3}$ & $2.538 \cdot 10^{-3}$ & $3.892 \cdot 10^{-3}$ & $9.40 \cdot 10^{-4}$ & $1.65 \cdot 10^{-3}$ \\
\hline $3-4$ & $1.32 \cdot 10^{-4}$ & $7.065 \cdot 10^{-4}$ & $9.022 \cdot 10^{-4}$ & $5.666 \cdot 10^{-4}$ & $8.788 \cdot 10^{-6}$ \\
\hline $4-4$ & $3.370 \cdot 10^{-7}$ & $6.05 \cdot 10^{-8}$ & $5.848 \cdot 10^{-8}$ & $5.997 \cdot 10^{-8}$ & $3.013 \cdot 10^{-8}$ \\
\hline
\end{tabular}

Table 7. Calculation results of maximum stress values according to the open/closed state of the valve

\begin{tabular}{|c|c|c|c|c|c|c|c|c|c|}
\hline \multirow{2}{*}{$\begin{array}{c}\text { Valve } \\
\text { open state }\end{array}$} & \multicolumn{10}{|c|}{ Maximum stress values [MPa] } \\
\cline { 2 - 12 } & Tub 1 & Seat 1 & Ring 1-1 & Ring 1-2 & Gate & Seat 2 & Ring 2-1 & Ring 2-2 & Tub 2 \\
\hline $0-4$ & 92.313 & 99.598 & 62.086 & 36.236 & 115.05 & 14.87 & 11.415 & 7.731 & 10.15 \\
\hline $1-4$ & 16.956 & 33.011 & 12.765 & 8.70 & 38.634 & 25.236 & 4.677 & 1.887 & 4.91 \\
\hline $2-4$ & 3.491 & 8.483 & 3.102 & 1.963 & 13.339 & 7.709 & 1.545 & 0.567 & 1.199 \\
\hline $3-4$ & 0.413 & 0.604 & 0.418 & 0.255 & 1.322 & 1.589 & 0.248 & 0.130 & 0.349 \\
\hline $4-4$ & 0.075 & 0.056 & 0.050 & 0.03 & 0.053 & 0.042 & 0.026 & 0.015 & 0.024 \\
\hline
\end{tabular}

The model of the valve for analysis was designed by using AutoCAD according to the standard and operating conditions of type $21 / 16 \quad-3 / 5 \mathrm{M}$ type gate valve actually used in the oil pipelines (Figure 9).

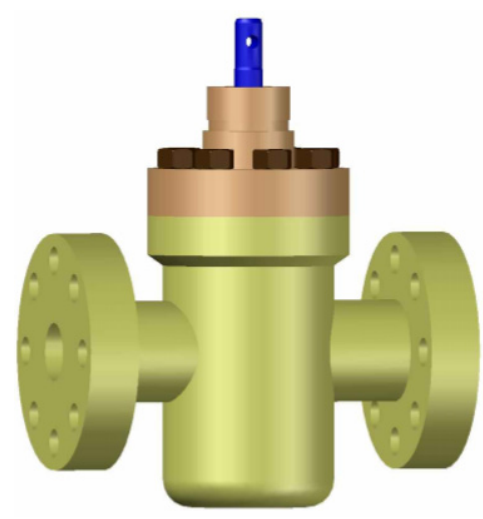

Figure 9. Gate valve model for stress analysis

For analysis, both surfaces of the valve were fixed and contact conditions between the parts were established. The model used for calculation was designed to be the same as the size of the actual valve, and the Von Mises method was used for stress calculation.
The calculation results are presented in Figures 10 and 11 , and in Table 7.

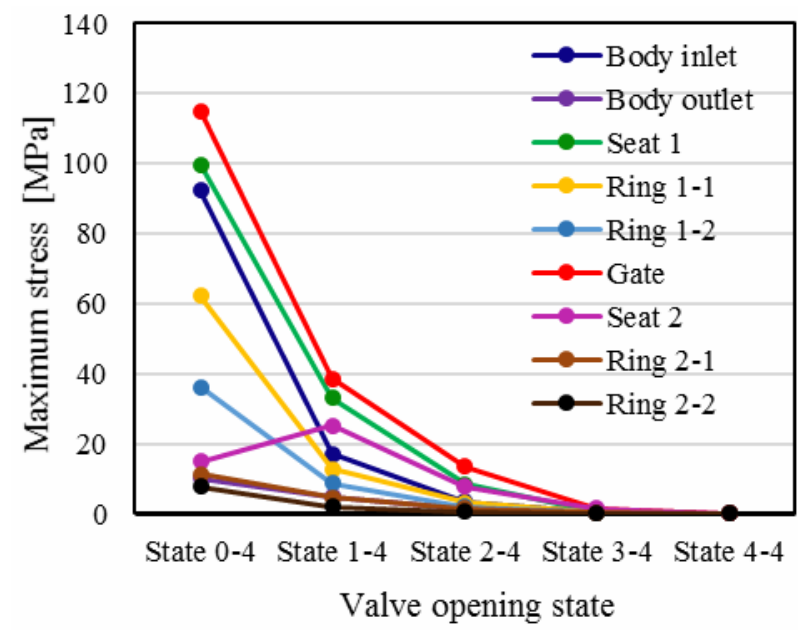

Figure 10. Changes of the maximum stress values acting on each part depending on the opening and closing state of the valve

As Figure 10 shows, the smaller the fluid passage area is, the bigger the value of the tension on the inner surface of the inlet part of the valve body is, and the 
tension on the gate wall reaches the maximum value when the valve is completely closed. Of course, in this case, the maximum tension was produced near the boundary between the wall in front of the gate and the valve seat1.

However, given that the maximum value of the calculated stress is $115.05 \mathrm{MPa}$, which is less than the permissible value of the material (yield stress of gate material $=460 \mathrm{MPa}$ ), the valve is considered to be stable in terms of structurally real working conditions.

As can be seen from Table 7, maximum values were generated near the boundary between the gate and the seat 1 or between the gate and the seat 2 as the valve gate gradually is closed.

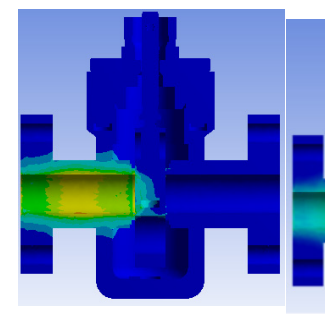

$0-4$

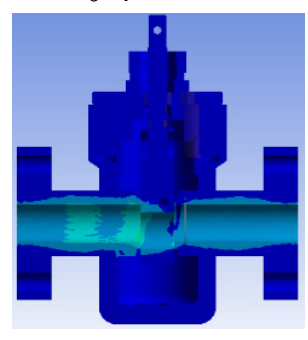

$3-4$

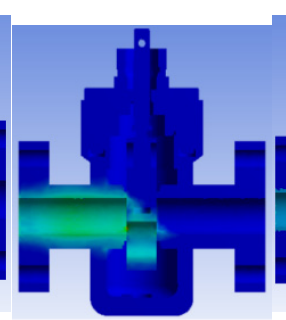

$1-4$

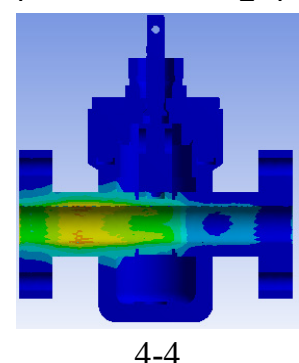

Figure 11. Changes of the stress distribution according to the open/close state of the gate valve

In addition, at the valve in which the gate was fully opened, the value of the stress was reduced as it went to the tube 2 , and in this case, the maximum value was produced on the inner surface of the inlet part of the valve body. Of course, the value in this case was $0.075 \mathrm{MPa}$, which was lower than the maximum values obtained in other cases.

\section{CONCLUSION}

This research presented the process of evaluating the erosion and the structural stability on the gate valve where the multiphase fluid flows, using Ansys Fluent 19.2. Using the DPM model, the flow characteristics and the change in erosion rates on the valve were calculated, and in this process it was confirmed that the erosion phenomenon appeared most seriously on the inner surface of the gate, where the flowing direction of the fluid changed rapidly.

In addition, using the Von Mises method it is confirmed that the valve is structurally stable even when the valve is under maximum pressure. Of course, it is true that the accuracy of Ansys analysis results should be confirmed by experimental methods, however this method of analysis suggests that the gate, seat, and inner surface of the body behind the gate should be covered with good wear-resistant material to increase the valve durability.
It has also been confirmed again that to reduce the erosion rate we should avoid the fluid swirl by actuating the valve in the condition that the gate is completely opened or closed.

\section{REFERENCES}

[1] Finnie, I.: Erosion of Surfaces by Solid Particles, Wear, Vol. 3, No. 2, pp. 87-103, 1960.

[2] Deng, T., Patel, M., Hutchings, I. and Bradley, M.S.A.: Effect of Bend Orientation on Life and Puncture Point Location Due to Solid Particle Erosion of a High Concentration Flow in Pneumatic Conveyors, Wear, Vol. 258, Issues 1-4, pp. 426433, January 2005.

[3] Madani Sani, F., Huizinga, S., Esaklul, K.A. and Nesic, S.: Review of the API RP 14E erosional velocity equation: Origin, applications, misuses, limitations and alternatives, Wear 426-427, pp. 620-636, 2019.

[4] McLaury, B.S. and Shirazi, S.A.: Generalization of API RP 14E for Erosive Service in Multiphase Production, in: Session, Production operations and engineering/general, Your building blocks for the future, 1999, Houston, TX, Society of Petroleum Engineers, pp.423-432.

[5] Arabnejad, H., Mansouri, A., Shirazi, S.A. and McLaury, B.S.: Evaluation of Solid Particle Erosion Equations and Models for Oil and Gas Industry Applications, in: SPE Annual Technical Conference and Exhibition, 28-30. September 2015, Houston, Texas, USA, Society of Petroleum Engineers, pp. 2-19.

[6] McLaury, B.S., Shirazi, S.A., Shadley, J.R. and Rybicki, E.F.: Modeling Erosion in Chokes, in: Symposium, Erosion processes: Proceedings of the ASME Fluids Engineering Division Summer Meeting-1996-, 1996, San Diego, California, pp.773-782.

[7] Edwards, J.K., McLaury, B.S. and Shirazi, S.A.: Supplementing a CFD Code with Erosion Prediction Capabilities, in: ASME FED Summer Meeting, Paper No. FEDSM98-5229, June 21-25, 1998, Washington D.C.

[8] Oka, Y.I. and Yoshida, T.: Practical Estimation of Erosion Damage Caused by Solid Particle Impact, Part 2: Mechanical Properties of Materials Directly Associated With Erosion Damage, Wear, Vol. 259, Issues 1-6, pp. 102-109, 2005.

[9] Messa, G.V., Negri, M., Wang, Y. and Malavasi, S.: Estimation of the Useful Lifetime of a Gate Valve Subjected to Impact Erosion, in: AIMETA 2017 XXIII Conference The Italian Association of Theoretical and Applied Mechanics, 4-7. September 2017, Salerno, Italy, pp.147-161.

[10] Det Norske Veritas (DNV): Erosive Wear in Piping Systems, Recommended Practice RP 0501, Revision 4.2-2007, January 2011, pp10-15.

[11] Muzychka, Y.S. and Yovanovich, M.M.: Convective Heat Transfer, in: Richard, W. Johnson, (Ed.): Handbook of Fluid Dynamics, 
Second Edition, Boca Raton, London, New York, CRC PRESS, pp. 34(14), 03.09.2016.

[12] Chongyong Nam, Yongkyu Lee, Gunhee Park, Gunhak Lee and Won Bo Lee: Analysis of Pipe Failure Period Using Pipe Elbow Erosion Model by Computational Fluid Dynamics (CFD), Korean Chem. Eng. Res., Vol. 56, No. 1, pp. 133-138, February 2018.

[13] Osama A. Marzouk E. David Huckaby: Simulation of a Swirling Gas-Particle Flow Using Different kEpsilon Models and Particle-Parcel Relationships, Engineering Letters, 18:1, EL_18_1_07, 1 February 2010 (Advance online publication).

[14] Kim, S.-E., Choudhury, D., Patel, B.: Computations of Complex Turbulent Flows Using the Commercial Code Fluent, in: Salas, M.D., Hefner, J.N. and Leonidas Sakell (Ed.): Modeling Complex Turbulent Flows, Kluwer Academic Publishers, Hampton, pp. 259-276, 1997.

[15] Tsan-Hsing Shih, William W. Liou, Aamir Shabbir, Zhigang Yang and Jiang Zhu: A New $k$ - Eddy Viscosity Model for High Reynolds Number Turbulent Flows, Computers \& Fluids, Vol. 24, Issue 3, March 1995, pp.227-238.

[16] Vencl, A., Bobić, I., Bobić, B., Jakimovska, K., Svoboda, P., Kandeva, M., Erosive wear properties of ZA-27 alloy-based nanocomposites: Influence of type, amount and size of nanoparticle reinforcements, Friction, 7, 4, pp.340-350, 2019.

[17] Edwards, J.K., McLaury, B.S., Shirazi, S.A.: Evaluation of Alternative Pipe Bend Fittings in Erosive Service, in: Summer meeting, American Society of Mechanical Engineers, Fluids Engineering Division, June 2000, Boston, MA, pp. 959-966.

\section{NOMENCLATURE}

$\begin{array}{ll}R e & \text { Reynolds number } \\ D & \text { Diameter of valve } \\ L_{\text {tube,turbulent }} & \text { Length of a pipe } \\ C_{f} & \text { Coefficient of surface friction } \\ u & \text { Fluid flow velocity } \\ u_{\text {fric }} & \text { Velocity of solid particles } \\ y & \text { Mesh height or distance from the wall } \\ y^{+} & \text {Target value } \\ U_{\mathrm{i}}, U_{\mathrm{j}} & \text { Velocity vectors } \\ P^{\prime} & \text { Average pressure } \\ g_{\mathrm{i}} & \text { Gravitational acceleration }\left(9.81 \mathrm{~m} / \mathrm{s}^{2}\right) \\ S_{\mathrm{p}} & \text { Particle momentum } \\ k & \text { Turbulent kinetic energy per unit mas } \\ S_{\mathrm{ij}}^{\mathrm{dev}} & \text { Deviatoric (traceless) part of the strain- } \\ S_{\mathrm{ij}} & \text { rate tensor } S_{\mathrm{ij}} \\ P & \text { Strain-rate tensor } \\ R & \text { Production rate of kinetic energy (per } \\ f(\gamma) & \text { unit volume) } \\ V & \text { Erosion rate } \\ & \text { Function of the angle of impact } \\ & \text { Relative velocity of the particle }\end{array}$

$$
\begin{array}{ll}
A_{\text {face }} & \text { Area of the element on the wall. } \\
N_{\text {particles }} & \text { Number of particles }
\end{array}
$$

\section{Greek symbols}

$\begin{array}{ll}\tau_{\mathrm{w}} & \text { Tangential stress } \\ \rho & \text { Fluid density } \\ \mu & \text { Fluid viscosity } \\ \sigma_{\mathrm{ij}} & \text { Viscous stress tensor } \\ \tau_{\mathrm{ij}} & \text { Reynolds (or turbulent) stress tensors } \\ \varepsilon & \text { Turbulent dissipation rate } \\ \mu_{\mathrm{t}} & \text { Turbulent (or eddy) viscosity } \\ \eta & \text { Ratio of the turbulent to mean-strain } \\ \Omega_{\mathrm{ij}} & \text { time scales } \\ \gamma & \text { Rate of rotation tensor } \\ & \text { Angle of impact between the wall and }\end{array}$

\section{Superscripts}

dev. Deviatoric (traceless) part

$\mathrm{b}(v) \quad$ Function of the relative velocity of the particle

\section{МОДЕЛИРАЊЕ ЕРОЗИЈЕ КОД ПАРАЛЕЛНОГ ПРОТОЧНОГ ВЕНТИЛА}

\section{Ј.Х. Ри, Р-Г. Рипеану, А. Динита}

Ерозију проточних вентила, који имају широку примену у производњи и транспорту нафте, може да изазове висок притисак флуида и честице песка које се налазе у сировој нафти. Она може да доведе до смањења дебљине вентила и затварања система за експлоатацију нафте. Не јавља се равномерно код свих делова вентила и разликује се код различитих фаза отварања вентила. Коришћењем програма ANSYS Fluent 19.2 извршена је анализа протока и брзине настанка ерозије при кретању флуида кроз вентил у различитим фазама отварања вентила. Модел вентила је израђен помоћу програма AutoCAD, док су геометријске димензије и физичка својства материјала одређена према спецификацијама проточног вентила инсталираног у нафтоводу. Израчунавањима преко Рејнолдсовог броја утврђено је да флуид који пролази кроз вентил има карактеристике турбулентног струјања, и на основу овог израчунавања одређена је дужина улаза вентила. За CFD анализу коришћени су Ојлеров као и Лагранжов метод. Применом модела $\kappa-\varepsilon$ и DPM према карактеристикама турбулентног струјања предвиђена је брзина развоја ерозије површине коју изазива песак који је у чврстој фази и диспергован у флуиду. На основу Мизеовог метода и дистрибуције притиска, као и података добијених анализом флуида, приказан је поступак израчунавања напона на компонентама за затварање. Флуид коришћен за анализу је била нафта са честицама песка. 